\title{
Pengaruh Hormon dan Ukuran Eksplan terhadap Pertumbuhan Mata Tunas Tanaman Pisang (Musa paradisiaca var. Raja Bulu) Secara In Vitro
}

\section{The Hormone Effect and Explant Size to The Growth of Banana Shoot (Musa paradisiaca var. Raja Bulu ) In Vitro}

\author{
Fifit Yuniati $^{1}$, Sri Haryanti ${ }^{2}$, Erma Prihastanti ${ }^{2}$ \\ ${ }^{1)}$ Program Studi Biologi, Departemen Biologi, Fakultas Sains dan Matematika, Universitas Diponegoro \\ ${ }^{2}$ Departemen Biologi, Fakultas Sains dan Matematika, Universitas Diponegoro \\ Jl. Prof. Soedarto, SH, Tembalang, Semarang \\ *Email: fit_ufp@yahoo.co.id
}

Diterima 9 Desember 2016 / Disetujui 30 Januari 2018

\begin{abstract}
ABSTRAK
Penggunaan eksplan mata tunas pisang (Musa paradisiaca var. Raja Bulu) diduga lebih efektif membentuk tunas secara langsung, sehingga dapat memotong satu tahapan kultur in vitro. Tujuan penelitian ini mengetahui kombinasi hormon dan ukuran eksplan yang terbaik untuk pertumbuhan mata tunas secara in vitro. Penelitian ini menggunakan Rancangan Acak Lengkap (RAL) faktorial (4x2) dengan 3 kali ulangan. Faktor pertama hormon (P) yaitu P0: tanpa zat pengatur tumbuh, P1: IAA 0,5 mg/l + BA 4,5 mg/l, P2: IAA 3 $\mathrm{mg} / \mathrm{l}+\mathrm{BA} 7 \mathrm{mg} / \mathrm{l}$, P3: IAA 5,5 mg/l + BA 9,5 mg/l. Faktor kedua ukuran eksplan yaitu B: mata tunas besar $(3-4 \mathrm{~cm})$ dan $\mathrm{K}$ : mata tunas kecil $(1-2 \mathrm{~cm})$. Parameter yang diamati adalah bobot, diameter, warna, morfologi mata tunas dan browning. Data dianalisis dengan Analysis of Variance (ANOVA) dan jika ada beda pengaruh diuji lanjut Duncan'(DMRT) signifikansi 95\%. Hasil penelitian menunjukkan terdapat interaksi perlakuan kombinasi hormon dan ukuran mata tunas terhadap diameter mata tunas, namun tidak terdapat interaksi terhadap bobot mata tunas. Perlakuan hormon dan ukuran mata tunas masing - masing berpengaruh nyata terhadap bobot mata tunas. Interaksi hormon IAA $5,5 \mathrm{mg} / \mathrm{l}+\mathrm{BA} \quad 9,5 \mathrm{mg} / \mathrm{l}$ dan mata tunas besar menghasilkan diameter mata tunas paling tinggi, sedangkan masing-masing perlakuan menghasilkan bobot mata tunas paling tinggi. Kombinasi hormon IAA $0,5 \mathrm{mg} / \mathrm{l}+\mathrm{BA} \quad 4,5 \mathrm{mg} / \mathrm{l}$ menghasilkan diameter paling tinggi pada mata tunas kecil. Semua perlakuan kombinasi hormon dan mata tunas menyebabkan eksplan membengkak dan mengelupas kecuali pada kombinasi hormon IAA $3 \mathrm{mg} / \mathrm{l}$ + BA $7 \mathrm{mg} / \mathrm{l}$ eksplan hanya membengkak. Warna eksplan menjadi hijau seiring dengan bertambahnya bobot.
\end{abstract}

Kata kunci : mata tunas, Raja Bulu, IAA, BA.

\section{ABSTRACT}

The use of buds explants pisang (Musa paradisiaca var. Raja Bulu) expected to be more effective that is expected to form shoots directly so as to cut the stage in vitro culture. The purpose of this study to determine the balance of hormones and explant size is best for the growth of the banana king feather buds in vitro. This study uses a Completely Randomized Design (CRD) factorial $(4 \times 2)$ with 3 replications. The first factor hormone (P) ie P0: without growth regulators, P1: IAA $0.5 \mathrm{mg} / 1+\mathrm{BA} 4.5 \mathrm{mg} / \mathrm{l}$, P2: IAA $3 \mathrm{mg} / 1+\mathrm{BA} 7$ $\mathrm{mg} / 1$, P3: IAA $5.5 \mathrm{mg} / 1 \mathrm{BA}+9.5 \mathrm{mg} / 1$. The second factor is the size of the buds explant ie B: buds large diameter $(3-4 \mathrm{~cm})$ and $\mathrm{K}$ : buds small diameter $(1-2 \mathrm{~cm})$. The parameters were the weight, diameter, color, morphology changes buds and browning. Data were analyzed using Analysis of Variance (ANOVA) and if there are different influences continued of Duncan '(DMRT) 95\% significance. The results showed that there is a balance of hormone treatment interaction and the size of the buds to the increase in diameter buds, but there is no interaction against weight gain buds. The treatment of the balance of hormones and the size of the buds each - each significantly affect weight gain buds. Interaction IAA hormone balance of $5.5 \mathrm{mg} / 1 \mathrm{BA}+$ $9.5 \mathrm{mg} / 1$ and large buds produce the increase in diameter highest buds, while each of these treatments produce weight gain highest buds. IAA hormone balance of $0.5 \mathrm{mg} / 1+\mathrm{BA} 4.5 \mathrm{mg} / 1$ resulted in the increase in diameter was highest in small buds. All treatments balance of hormones and cause explant buds swell and 
peel unless the balance of hormones IAA treatment $3 \mathrm{mg} / 1+\mathrm{BA} 7 \mathrm{mg} / 1$ just cause explants swell. Explants color changes to green with increasing weight.

Keywords : buds, raja bulu, IAA, BA

\section{PENDAHULUAN}

Tanaman Pisang Raja Bulu merupakan tanaman monokotil, sistem perakarannya sangat kuat, dan berumur genjah/ cepat berbuah (12-15 bulan) (Siregar dkk, 2013). Berdasarkan keterangan eksportir buah-buahan di Jakarta, pisang Raja Bulu merupakan jenis pisang yang diminati di Saudi Arabia dan negara pengimpor lainnya (Maslukha, 2008). Hal ini mendorong petani ataupun pengusaha agribisnis membudidayakan pisang Raja Bulu secara komersial pada skala usaha yang lebih luas, baik untuk memenuhi pasar lokal maupun ekspor (Supriyati, 2011).

Teknologi budidaya pisang cakupannya luas, namun yang paling dasar dan sangat menentukan hasil adalah penyediaan bibit yang bermutu (Dewi, 2016). Penyediaan bibit melalui kultur jaringan sangat dimungkinkan mendapatkan bahan tanam dalam jumlah besar dalam waktu singkat bibit kondisinya sehat dan seragam (Nisa dan Rodinah, 2005), namun ditemukan kendala berupa pertumbuhan bibit yang lambat pada pisang raja Bulu (Isnaini, 2016). Hal tersebut disebabkan oleh eksplan yang bersifat spesifik, dominansi apikal sangat kuat, dan sulit berproliferasi membentuk tunas (Kasutjianingati dkk, 2010). Upaya untuk mengatasi permasalahan tersebut sangat diperlukan, salah satunya dengan menambahkan zat pengatur tumbuh secara tepat pada media kultur.

Pertumbuhan dan morfogenesis eksplan diatur oleh interaksi dan keseimbangan zat pengatur tumbuh pada media dengan hormon endogen yang terdapat dalam eksplan (Rainiyati dkk, 2007). IAA (Indole Acetic Acid) merupakan auksin yang aktif di dalam tumbuhan (endogenous) yang diproduksi dalam jaringan meristematik yang aktif (Ardiyani dan Rina, 2012). BA (Benzyl Adenin) merupakan jenis sitokinin sintetik yang mempunyai aktivitas yang kuat, lebih efektif daripada kinetin karena BA mempunyai gugus benzil (Lestari, 2011).
Nisa dan Rodinah (2005) menyatakan bahwa dalam pertumbuhan jaringan, sitokinin bersama-sama dengan auksin memberikan pengaruh interaksi terhadap deferensiasi jaringan. Alitalia (2008) menyebutkan bahwa nisbah sitokinin-auksin yang tinggi akan mendorong pembentukan tunas. Ernawati dkk, (2005) melakukan percobaan inisiasi menggunakan kombinasi hormon BAP $7 \mathrm{mg} / \mathrm{l}+3$ IAA $\mathrm{mg} / \mathrm{l}$, mampu menghasilkan tunas mikro eksplan jantung pisang Rajabulu sebanyak 12 tunas pada musim kemarau dan 6 tunas pada musim penghujan, sedangkan eksplan anakan sebanyak 5 tunas pada musim kemarau dan 7 tunas pada musim penghujan.

Penelitian ini akan dilakukan kultur in vitro menggunakan eksplan mata tunas pisang (Musa paradisiaca var. Raja Bulu) pada medium MS dengan penambahan kombinasi hormon IAA dan BA yang bertujuan untuk mengetahui imbangan hormon IAA dan BA yang terbaik untuk pertumbuhan mata tunas. Mata tunas merupakan organ yang tersusun oleh jaringan muda yang selselnya masih aktif membelah (meristematik). Mata tunas memiliki ukuran diameter yang berbedabeda yang menunjukkan fase pertumbuhan secara fisiologi yang berbeda pula, sehingga digunakan ukuran diameter mata tunas untuk mengetahui pertumbuhan yang lebih optimum secara in vitro. Penggunaan mata tunas pada kultur in vitro diduga lebih efektif karena sudah terbentuk calon tunas yang diharapkan dapat membentuk tunas secara langsung sehingga dapat memotong satu tahapan kultur in vitro.

\section{METODE PENELITIAN}

\section{Waktu dan Tempat}

Penelitian dilaksanakan pada bulan Juli sampai dengan September 2016 di Laboratorium Biologi Struktur dan Fungsi, Departemen Biologi, Fakultas Sains dan Matematika, Universitas Diponegoro. 
Bahan yang digunakan meliputi mata tunas pisang (Musa paradisiaca var. Raja Bulu) yang diperoleh dari UPTD Balai Benih Pertanian Kota Semarang, media dasar MS, IAA, BA, aquades steril, $\mathrm{HCl}, \mathrm{NaOH}$, fungisida, bakterisida, alkohol $70 \%$, alkohol $96 \%, \mathrm{H}_{2} \mathrm{O}_{2}$, betadine, spiritus, sabun cair, bayclin, agar-agar, myoinositol, gula pasir, tisu, alumunium foil, plastik wrap cling, dan air.

\section{Cara Kerja}

1. Sterilisasi Alat dan Botol : semua alat dicuci dengan sabun cair dan dibilas hingga bersih kemudian dikeringkan. Setelah kering dibungkus dengan kertas, sedangkan botol kultur ditutup dengan alumunium foil. lalu disterilkan dalam autoklaf (pada suhu $121^{\circ} \mathrm{C}$ pada tekanan 1 atm, 30 menit). Selanjutnya alat-alat diletakkan di dalam oven.

2. Pembuatan Larutan Stok ZPT: IAA (4 mg) dan BA $(5 \mathrm{mg})$ ditempatkan pada gelas piala yang berbeda. kemudian IAA dilarutkan terlebih dahulu dengan $\mathrm{NaOH}$, sedangkan $\mathrm{BA}$ dilarutkan terlebih dahulu dengan $\mathrm{HCl}$. Kemudian masing-masing ditambahkan aquadest sampai $200 \mathrm{ml}$, kemudian diaduk dengan magnetic stirer tanpa pemanasan sampai larut dan homogen, lalu dimasukkan dalam botol dan ditutup kemudian disimpan dalam refrigerator.

3. Pembuatan 1 liter Media: garam-garam dari media MS yang telah dibuat menjadi larutan stok diambil sesuai dengan konsentrasi yang dibutuhkan dan ditambah IAA dan BA (sesuai perlakuan). Kemudian ditambahkan gula (30 g) dan akuadest hingga mencapai $800 \mathrm{ml}$. Penyesuaian $\mathrm{pH}$ antara 5,6-5,8 dengan menambahkan $\mathrm{NaOH} 0,1 \mathrm{~N}$ bila $\mathrm{pH}$ kurang dari 5,6 dan ditambahkan $\mathrm{HCl} 0,1 \mathrm{~N}$ bila $\mathrm{pH}$ lebih besar dari 5,8. Selanjutnya ditambahkan agaragar (7 g) dan akuadest sampai volume media mencapai 1 liter, dan dipanaskan sambil diaduk hingga mendidih dan homogen. Kemudian media dimasukkan ke dalam botol kultur steril, lalu ditutup dengan alumunium foil dan plastik wrap cling, kemudian disterilisasi dengan autoklaf (20 menit).
4. Persiapan Eksplan: Mata tunas diambil dari pohon anakan pisang yang berasal dari induk yang pernah berbuah dan unggul. Mata tunas dipilih dengan ukuran mata tunas kecil $(\mathrm{K}=$ diameter 1-2 cm) dan besar $(B=$ diameter $3-4$ $\mathrm{cm})$ dengan ciri-ciri berwarna putih dan lunak. Mata tunas ini diambil dan dimasukkan ke dalam kantong plastik hitam.

5. Sterilisasi Eksplan dan Penanaman:

- Mata tunas dicuci dengan sabun cair dan dibilas hingga bersih, lalu dimasukkan ke dalam botol berisi fungisida $(2 \mathrm{~g} / \mathrm{l})$ dan bakterisida $(2 \mathrm{~g} / \mathrm{l})$, lalu botol ditutup dan didiamkan selama 24 jam. Selanjutnya diambil dan dimasukkandala ke dalam LAF yang sudah disterilkan dengan alkohol $70 \%$ dan disinari sinar UV (30 menit)penyinaran dihentikan lampu blow dinyalakan. Selanjutnya eksplan dikupas sekali lalu dicuci dengan akuadest steril (1 menit, 3 kali), lalu direndam dalam larutan $\mathrm{H}_{2} \mathrm{O}_{2} \quad 10 \%$ (10 menit) sambil digojok, kemudian dicuci dengan akuades steril (1 menit, 3 kali). Lalu eksplan dimasukkan ke dalam larutan bayclin 30\% (30 menit), 20\% (20 menit), dan 10\% (10 menit) secara berurutan sambil digojog.

- Selanjutnya dibilas dengan akuades steril digojok selama 10 menit, dibilas lagi 5 menit. Selanjutnya eksplan dikupas sekali lagi lalu dicuci akuadest steril dan betadine 5 menit lalu eksplan diletakkan petridish dan ditanam pada media kultur dengan pinset steril dan botol ditutup alumunium foil dan plastik wrap cling.

6. Pemeliharaan pada ruang steril, pencahayaan lampu neon daya $10 \mathrm{Watt} / J$ oule (24 jam), suhu ruangan $25^{\circ} \mathrm{C}$. Setiap 3 hari sekali botol kultur disemprot dengan alkohol $70 \%$.

Penelitian ini menggunakan Rancangan Acak Lengkap (RAL) Faktorial (4x2). Faktor pertama hormon dan faktor kedua ukuran mata tunas, yaitu :

1. Kombinasi hormon :

$\mathrm{P} 0=$ tanpa zpt (zat pengatur tumbuh)

$\mathrm{P} 1=\mathrm{IAA} 0,5 \mathrm{mg} / \mathrm{l}+\mathrm{BA} 4,5 \mathrm{mg} / \mathrm{l})$

$\mathrm{P} 2=\mathrm{IAA} 3 \mathrm{mg} / \mathrm{l}+\mathrm{BA} 7 \mathrm{mg} / \mathrm{l})$

P3 = IAA 5,5 mg/l + BA 9,5 mg/l)

2. Ukuran diameter :

$\mathrm{B}=$ mata tunas besar (diameter $3-4 \mathrm{~cm}$ )

$\mathrm{K}=$ mata tunas kecil (diameter $1-2 \mathrm{~cm}$ ) 
Masing-masing perlakuan dengan 3 ulangan, setiap botol kultur masing-masing berisi satu eksplan.

\section{Parameter Penelitian}

1. Penambahan bobot mata tunas: ditentukan dengan rumus $=$ bobot akhir $\left(\mathrm{B}_{\mathrm{t}}\right)-$ bobot awal $\left(\mathrm{B}_{\mathrm{o}}\right)$.

2. Penambahan diameter mata tunas: diukur lebar bagian bawah titik tumbuh utama dari sisi satu ke sisi lainnya yang diukur diluar botol. Pengamatan dilakukan setiap 1 minggu sekali sampai akhir pengamatan (4 MST).

3. Warna mata tunas: diamati setiap satu minggu sekali sampai akhir pengamatan (4 MST) dengan skoring: $0=$ coklat; $1=$ putih kecoklatan $2=$ putih; $3=$ kuning; $4=$ hijau muda; $5=$ hijau; $6=$ hijau tua.

4. Perubahan morfologi dan browning pada eksplan: diamati secara visual setiap hari sampai akhir pengamatan (30 HST).

\section{Analisis Data}

Data bobot dan diameter mata tunas dianalisis dengan ANOV taraf signifikansi 95\% dan jika ada beda pengaruh dilanjutkan dengan uji Duncan'(DMRT).

\section{HASIL DAN PEMBAHASAN}

\section{Rata - rata pertambahan bobot mata tunas pisang Raja Bul}

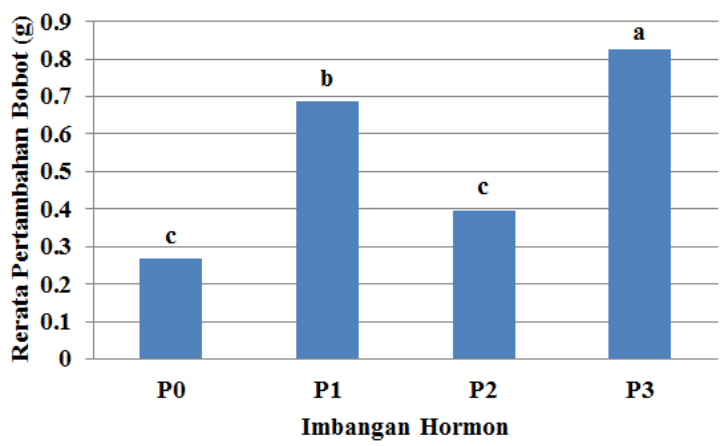

Gambar 1. Histogram rata-rata pertambahan bobot mata tunas pisang Raja Bulu pada perlakuan hormon selama 30 hari

Keterangan : $\mathrm{P} 0=$ tanpa zpt; $\mathrm{P} 1=0,5 \mathrm{mg} / \mathrm{l} \mathrm{IAA}+4,5$ $\mathrm{BA} \mathrm{mg} / \mathrm{l} ; \mathrm{P} 2=3 \mathrm{mg} / \mathrm{lAA}+7 \mathrm{BA} \mathrm{mg} / \mathrm{l}$ $\mathrm{P} 3=5,5 \mathrm{mg} / \mathrm{IAA}+\mathrm{BA} 9,5 \mathrm{mg} / \mathrm{l}$
Hasil uji ANOVA (Analysis of Variance) pada taraf signifikansi $95 \%$ terhadap bobot mata tunas pisang Raja Bulu menunjukkan bahwa tidak terdapat interaksi perlakuan kombinasi hormon dan ukuran mata tunas. Uji lanjut pengaruh hormon memberikan pengaruh nyata terhadap bobot mata tunas (Gambar 1).

Perlakuan hormon menghasilkan rata-rata bobot mata tunas meningkat terutama pada $\mathrm{P} 1$ da P3 dibandingkan kontrol. Hal ini dikarenakan hormon eksogen IAA dan BA yang diberikan pada eksplan akan meningkatkan konsentrasi hormon endogen pada eksplan, yang kemudian merangsang aktivitas sel untuk membelah dan membentang, sehingga mengakibatkan mata tunas tumbuh lebih cepat. Perlakuan imbangan hormon IAA $5,5 \mathrm{mg} / \mathrm{l}+\mathrm{BA} \quad 9,5 \mathrm{mg} / \mathrm{l}(\mathrm{P} 3)$ menghasilkan bobot mata tunas paling tinggi yaitu $0,827 \mathrm{~g}$ (Gambar 1).

Menurut Alitalia (2008), sitokinin mampu mendorong pembelahan sel. Aktivitas sitokinin sendiri dipengaruhi oleh auksin. Menurut Nisa dan Rodinah (2005), auksin meningkatkan sintesa protein, sehingga dapat digunakan sebagai sumber tenaga dalam pertumbuhan. Hayati dkk, (2010) menyatakan bahwa auksin (IAA) pada media, akan berdifusi ke dalam sel-sel eksplan melalui luka pada ujung-ujung eksplan. Ketika IAA telah berada di dalam sel yang mempunyai $\mathrm{pH} 7$, IAA akan terionisasi yang menyebabkan IAA tetap berada di dalam sel dikarenakan membran plasma kurang permeabel terhadap ion. Kemudian, IAA akan mengaktifasi pompa proton (ion $\mathrm{H}^{+}$) yang terletak pada membran plasma, yang menyebabkan pH pada bagian dinding sel lebih rendah yaitu mendekati $\mathrm{pH}$ pada membran plasma (sekitar $\mathrm{pH}$ 4,5). Aktifnya pompa proton tersebut dapat memutuskan ikatan hidrogen diantara mikrofibril selulosa dinding sel yang menyebabkan dinding sel merenggang sehingga tekanan dinding sel akan menurun dan mengakibatkan pelenturan sel. Demikian, sel mudah mengambil air melalui osmosis dan sel akan bertambah panjang. Derajat keasaman $(\mathrm{pH})$ yang rendah juga dapat mengaktivasi enzim tertentu pada dinding sel yang dapat mendegradasi protein atau polisakarida yang menyebar pada dinding sel yang lunak dan lentur, sehingga pembesaran sel dapat terjadi. 
Menurut Hayati dkk (2010), peran sitokinin secara langsung adalah dalam proses transkripsi dan translasi RNA dalam proses sintesis protein yang berlangsung dalam tahap interfase. Proses translasi RNA dilanjutkan dengan pembentukan asam-asam amino yang merupakan komponen dasar protein. Protein yang terbentuk antara lain berupa enzim-enzim yang berperan dalam pembelahan sel, yaitu enzim polymerase DNA yang berperan dalam memperpanjang rantai DNA dan memperbaiki kesalahan penyusunan basa nitrogen pada DNA dan enzim ligase yang berperan dalam menggabungkan fragmen-fragmen DNA yang terputus-putus saat proses replikasi. Ketersediaan enzim-enzim ini di dalam sel akan menyebabkan proses pembelahan sel berlangsung lebih efektif.

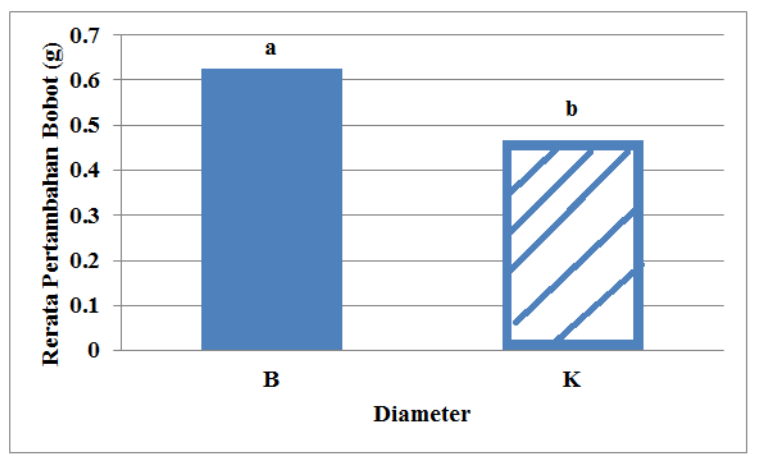

Gambar 2. Histogram rata-rata pertambahan bobot mata tunas pisang Raja Bulu pada diameter yang berbeda selama 30 hari

Keterangan : $\mathrm{B}=$ mata tunas besar (diameter $3-4 \mathrm{~cm}$ ); $\mathrm{K}=$ mata tunas kecil (diameter $1-2 \mathrm{~cm}$ )

Berdasarkan uji lanjut menunjukkan bahwa perlakuan ukuran mata tunas memberikan pengaruh nyata terhadap bobot mata tunas. bobot mata tunas lebih tinggi pada mata tunas ukuran besar (B) yaitu 0,625 gr (Gambar 2). Mata tunas mengandung karbohidrat, yang nantinya ketika ditanam pada media kultur akan melakukan katabolisme karbohidrat sebagai energi awal pertumbuhannya. Secara fisiologis, mata tunas besar (B) telah memiliki cadangan karbohidrat yang lebih banyak dibandingkan mata tunas kecil (K), yang mana sel-selnya akan membelah lebih cepat dan bertambah besar sehingga bobotnya pun bertambah. Untuk itu, penggunaan eksplan mata tunas sebaiknya diambil yang berukuran minimal 3 $\mathrm{cm}$.

\section{Pertambahan diameter mata tunas pisang Raja Bulu}

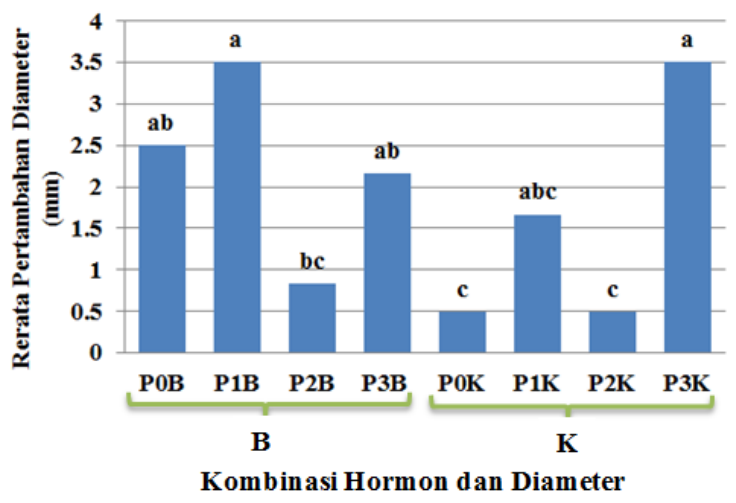

Gambar 3. Histogram rata-rata pertambahan ukuran diameter mata tunas pisang Raja Bulu pada kombinasi hormon pada diameter mata tunas yang berbeda selama 30 hari

Keterangan : $\mathrm{P} 0 \mathrm{~B}=$ tanpa $\mathrm{zpt}+$ mata tunas besar (diameter 3 - $4 \mathrm{~cm}$ ); P1B = 0,5 mg/l IAA $+4,5 \mathrm{BA} \mathrm{mg} / \mathrm{l}+$ mata tunas besar ; $\mathrm{P} 2 \mathrm{~B}=$ $3 \mathrm{mg} / \mathrm{l} \mathrm{IAA}+7 \mathrm{BA} \mathrm{mg} / \mathrm{l}+$ mata tunas besar ; $\mathrm{P} 3 \mathrm{~B}=5,5 \mathrm{mg} / \mathrm{l} \mathrm{IAA}+9,5 \mathrm{BA}$ $\mathrm{mg} / \mathrm{l}+$ mata tunas besar $; \mathrm{P} 0 \mathrm{~K}=$ Tanpa zat pengatur tumbuh + mata tunas kecil (diameter $1-2 \mathrm{~cm}$ ); P1K = 0,5 mg/l IAA $+4,5 \mathrm{BA} \mathrm{mg} / \mathrm{l}+$ mata tunas kecil; $\mathrm{P} 2 \mathrm{~K}=$ $3 \mathrm{mg} / \mathrm{l} \mathrm{IAA} \mathrm{+} 7 \mathrm{BA} \mathrm{mg} / \mathrm{l}+$ mata tunas kecil ; $\mathrm{P} 3 \mathrm{~K}=5,5 \mathrm{mg} / \mathrm{l} \mathrm{IAA}+9,5 \mathrm{BA}$ $\mathrm{mg} / \mathrm{l}+$ mata tunas kecil.

Kombinasi hormon IAA $5,5 \mathrm{mg} / \mathrm{l}$ dan BA 9,5 mg/l (P3K) mampu menghasilkan pertambahan diameter paling tinggi pada mata tunas kecil namun tidak berbeda nyata dengan perlakuan kombinasi hormon IAA $0,5 \mathrm{mg} / \mathrm{l}$ dan BA $4,5 \mathrm{mg} / \mathrm{l}$ (P1K). Sedangkan kombinasi hormon IAA 0,5 $\mathrm{mg} / \mathrm{l}$ dan BA 4,5 mg/l (P1B) menghasilkan penambahan diameter paling tinggi pada mata tunas besar, namun tidak berbeda nyata dengan perlakuan tanpa zat pengatur tumbuh $(\mathrm{P} 0 \mathrm{~B})$ dan perlakuan kombinasi hormon IAA $5,5 \mathrm{mg} / \mathrm{l}$ dan BA 9,5 mg/l (P3B). Hal ini menunjukkan bahwa kombinasi hormon IAA dan BA yang sama 
memberikan pengaruh yang berbeda pada eksplan mata tunas dengan ukuran yang berbeda pula.

Pertambahan diameter pada perlakuan kombinasi hormon IAA 5,5 dan BA 9,5 mg/l lebih optimum diberikan pada eksplan mata tunas kecil yaitu 3,5 mm, sedangkan kombinasi hormon IAA 0,5 dan BA 4,5 mg/l lebih optimum diberikan pada eksplan mata tunas besar yaitu $3,5 \mathrm{~mm}$, tetapi keduanya tidak berbeda nyata (Gambar 3). Hal ini menunjukkan bahwa terdapat interaksi zat pengatur tumbuh dan hormon endogen pada eksplan. Mata tunas besar maupun kecil samasama tersusun oleh jaringan muda secara fisiologi. Hormon endogen pada mata tunas terdapat di pucuknya yang merupakan tempat awal munculnya tunas daun. Proporsi ukurannya, mata tunas besar memiliki pucuk lebih membentang daripada mata tunas kecil, yang memungkinkan mengandung hormon endogen lebih tinggi pada mata tunas kecil, sehingga mata tunas kecil membutuhkan penambahan zat pengatur tumbuh yang lebih tinggi untuk pertumbuhannya.

Kombinasi hormon IAA $3 \mathrm{mg} / \mathrm{l}$ dan BA 7 $\mathrm{mg} / \mathrm{l}$ (P2K) pada media kultur menghasilkan diameter mata tunas paling rendah pada mata tunas kecil namun tidak berbeda nyata dengan perlakuan pada mata tunas besar (P2B), perlakuan tanpa zat pengatur tumbuh (kontrol) pada mata tunas kecil (P0K), dan perlakuan IAA $0,5 \mathrm{mg} / \mathrm{l}$ dan BA 4,5 $\mathrm{mg} / \mathrm{l}$ pada kelompok mata tunas kecil (P1K). Kombinasi hormon IAA $3 \mathrm{mg} / \mathrm{l}$ dan BA $7 \mathrm{mg} / \mathrm{l}$ menghasilkan pertambahan diameter paling rendah dapat disebabkan oleh imbangan hormon IAA dan BA yang diberikan pada eksplan dan hormon endogen yang diproduksi oleh tanaman kemungkinan berada pada posisi yang stagnan menurut nisbah sitokinin dan auksin, yang dapat menyebabkan sel membelah dan membesar secara lambat dan tidak mengalami proses diferensiasi sel, sehingga tidak terjadi perkembangan jaringan pada eksplan. Menurut Samudin (2009), interaksi dan perimbangan zat pengatur tumbuh yang ditambahkan dalam media dan yang diproduksi oleh sel tanaman secara endogen menentukan kecepatan dan arah perkembangan suatu kultur. Penambahan auksin dan sitokinin eksogen pada konsentrasi yang tepat dapat memacu pertumbuhan eksplan, terutama pembentukan tunas.

\section{Perubahan warna dan morfologi mata tunas pisang Raja Bulu}

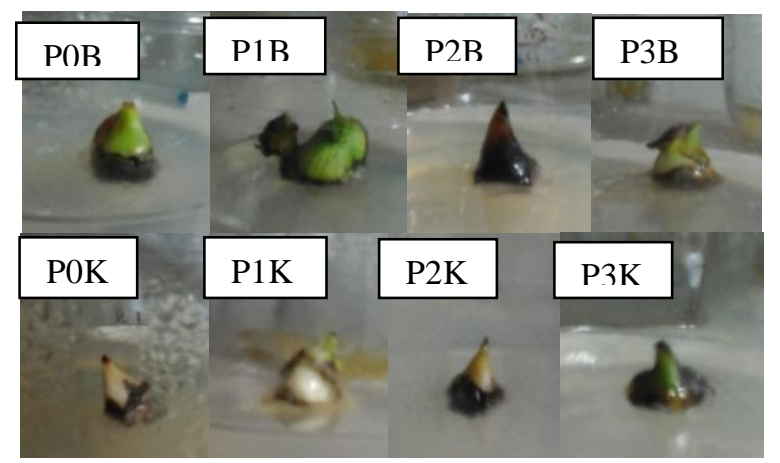

Gambar 4. Perubahan Warna Mata Tunas Pisang Raja Bulu selama 30 Hari

Tabel 1. Perubahan warna dan morfologi mata tunas pisang Raja Bulu selama 30 hari

\begin{tabular}{ccc}
\hline Perlakuan & Warna & $\begin{array}{c}\text { Perubahan } \\
\text { morfologi }\end{array}$ \\
\hline P0B & hijau & $\begin{array}{c}\text { bengkak, } \\
\text { mengelupas } \\
\text { bengkak, } \\
\text { mengelupas }\end{array}$ \\
P1B & hijau & Bengkak \\
P2B & $\begin{array}{c}\text { Kecoklata } \\
\text { n }\end{array}$ & bengkak, \\
P3B & hijau & mengelupas \\
muda & bengkak, \\
P0K & putih & mengelupas \\
bengkak, \\
P1K & hijau & muda \\
P2K & kuning & Bengkak \\
Pengkak, \\
P3K & hijau tua & mengelupas, tunas \\
\hline
\end{tabular}

Keterangan : $\mathrm{P} 0 \mathrm{~B}=$ tanpa $\mathrm{zpt}+$ mata tunas besar (diameter $3-4 \mathrm{~cm}$ ), P1B = 0,5 mg/l $\mathrm{IAA}+4,5 \mathrm{BA} \mathrm{mg} / \mathrm{l}+$ mata tunas besar, $\mathrm{P} 2 \mathrm{~B}=3 \mathrm{mg} / \mathrm{lAA}+7 \mathrm{BA} \mathrm{mg} / \mathrm{l}+$ mata tunas besar, $\mathrm{P} 3 \mathrm{~B}=5,5 \mathrm{mg} / \mathrm{l} \mathrm{IAA}+9,5$ BA $\mathrm{mg} / \mathrm{l}+$ mata tunas besar, $\mathrm{P} 0 \mathrm{~K}=$ Tanpa zat pengatur tumbuh + mata tunas kecil (diameter $1-2 \mathrm{~cm}), \mathrm{P} 1 \mathrm{~K}=$ $0,5 \mathrm{mg} / \mathrm{l} \mathrm{IAA}+4,5 \mathrm{BA} \mathrm{mg} / \mathrm{l}+$ mata tunas kecil , P2K = $3 \mathrm{mg} / \mathrm{l} \mathrm{IAA}+7 \mathrm{BA}$ $\mathrm{mg} / \mathrm{l}+$ mata tunas kecil, $\mathrm{P} 3 \mathrm{~K}=5,5 \mathrm{mg} / \mathrm{l}$ $\mathrm{IAA}+9,5 \mathrm{BA} \mathrm{mg} / \mathrm{l}+$ mata tunas kecil. 
Perlakuan tanpa zat pengatur tumbuh pada mata tunas besar berubah warna menjadi hijau, mengalami pembengkakan dan pengelupasan (Gambar 4). Menurut Rainiyati dkk (2009), eksplan yang dikulturkan pada kondisi di bawah cahaya mengalami perkembangan klorofil karena adanya rangsangan cahaya dan dimulainya proses fotosintesis. Terjadinya proses fotosintesis ini juga disertai dengan penyerapan unsur hara dan air dari media tanam sehingga terjadi pembesaran dan pembengkakan. Rahayu dkk, (2003) menyatakan bahwa sintesis klorofil terjadi melalui fotoreduksi protoklorofilid menjadi klorofilid a dan diikuti dengan esterifikasi fitol untuk membentuk klorofil a yang dikatalisis enzim klorofilase.

Berdasarkan Tabel 1. menunjukkan bahwa perlakuan tanpa zat pengatur tumbuh pada mata tunas kecil, eksplan tetap berwarna putih, dan sedikit membengkak. Menurut Maslukha (2008), auksin dalam kultur jaringan, selain berfungsi merangsang pemanjangan sel juga berfungsi dalam pembentukan klorofil. Rahayu dkk, (2003) menyebutkan kenaikan kadar auksin akan menurunkan kandungan klorofil. Penurunan kandungan klorofil diduga karena pengaruh auksin pada metabolisme karbohidrat. Apabila metabolisme karbohidrat terganggu maka sintesis klorofil juga akan terganggu.

Pembengkakan pada eksplan dalam media tanpa zat pengatur tumbuh dapat disebabkan oleh adanya hormon endogen dan cadangan makanan pada mata tunas. Menurut Marlin dkk (2012), sebagian besar berupa karbohidrat dan protein, yang akan terakumulasi pada jaringan luka, sehingga mengakibatkan eksplan membengkak.

Perlakuan kombinasi hormon IAA $0,5 \mathrm{mg} / \mathrm{l}$ dan BA 4,5 mg/l pada mata tunas besar mengalami perubahan warna hijau, sedangkan mata tunas kecil berwarna kehijauan, semua eksplan pada semua perlakuan membengkak, kemudian mengelupas (Gambar 4.). Menurut Hayati dkk (2010), keseimbangan konsentrasi auksin dan sitokinin dalam kultur in vitro diketahui dapat memacu pembesaran dan pembelahan sel.

Perlakuan kombinasi hormon IAA $3 \mathrm{mg} / \mathrm{l}$ dan BA $7 \mathrm{mg} / \mathrm{l}$ pada semua ukuran mata tunas mengalami respon paling lambat. Secara teknis, eksplan mengalami browning, sehingga mengakibatkan gangguan pada pertumbuhannya. Menurut Hutami (2008), perubahan warna menjadi coklat dalam kultur jaringan terjadi karena akumulasi polifenol oksidase yang dilepas atau disintesis jaringan dalam kondisi teroksidasi ketika sel dilukai, sehingga jaringan yang diisolasi menjadi berwarna coklat. Menurut Nisa dan Rodinah (2005), keberadaan sejumlah genom B mempengaruhi tingkat kandungan fenol dan aktivitas polifenol oksidase, yang mana semakin banyak jumlah genom B semakin tinggi pula aktivitas enzim polifenol oksidase.

Eksplan pada kombinasi hormon IAA 5,5 $\mathrm{mg} / \mathrm{l}$ dan BA 9,5 mg/l untuk mata tunas besar (P3B) sedikit membengkak dan menghijau, sedangkan pada kelompok mata tunas kecil (P3K), eksplan membengkak dan telah tumbuh tunas. Diduga kandungan hormon endogen berupa sitokinin pada mata tunas kecil kemungkinan lebih rendah daripada mata tunas besar, sehingga membutuhkan konsentrasi yang lebih tinggi untuk memacu pertumbuhan tunas. Sebaliknya, mata tunas besar membutuhkan konsentrasi yang lebih rendah untuk memacu pertumbuhannya.

Inisiasi tunas dipengaruhi oleh konsentrasi sitokinin yang optimum pada media. Menurut Kasutjianingati dkk (2010), perkembangan eksplan membentuk tunas tergantung dari zat pengatur tumbuh dan spesifikasi eksplan. Makin responsif eksplan terhadap konsentrasi sitokinin media, makin merangsang induksi tunas. Menurut Wijayani dkk (2007), induksi tunas terjadi melalui peristiwa diferensiasi sel yaitu sel yang sudah mencapai volume akhirnya menjadi terspesialisasi dengan cara tertentu. Menurut Eriansyah dkk (2014), eksplan berdiferensiasi dengan cara mengelupas seludangnya satu -persatu kemudian akan terbuka hingga kelapisan yang paling dalam dan akan mulai membentuk tunas.

\section{KESIMPULAN}

1. Terdapat interaksi perlakuan kombinasi hormon dan ukuran mata tunas terhadap pertambahan diameter mata tunas, namun tidak terdapat interaksi terhadap pertambahan bobot mata tunas. Kombinasi hormon dan ukuran mata tunas masing - masing 
berpengaruh nyata terhadap pertambahan bobot mata tunas.

2. Interaksi kombinasi hormon IAA $\mathrm{mg} / \mathrm{l}+\mathrm{BA} 9,5 \mathrm{mg} / \mathrm{l}$ dan mata tunas besar menghasilkan pertambahan diameter mata tunas paling tinggi, sedangkan masing-masing perlakuan tersebut menghasilkan pertambahan bobot mata tunas paling tinggi. Imbangan hormon IAA $0,5 \mathrm{mg} / \mathrm{l}+\mathrm{BA} \quad 4,5 \mathrm{mg} / \mathrm{l}$ menghasilkan diameter paling tinggi pada mata tunas kecil.

3. Semua kombinasi hormon dan ukuran mata tunas menyebabkan eksplan membengkak dan mengelupas kecuali perlakuan kombinasi hormon IAA $3 \mathrm{mg} / \mathrm{l}+\mathrm{BA} 7 \mathrm{mg} / \mathrm{l}$ hanya menyebabkan eksplan membengkak. Warna ekplan menjadi hijau seiring dengan bertambahnya bobot.

\section{DAFTAR PUSTAKA}

Alitalia, Y. 2008. Pengaruh Pemberian BAP dan NAA terhadap Pertumbuhan dan Perkembangan Tunas Mikro Kantong Semar (Nepenthes mirabilis) secara In Vitro. Skripsi. Program Studi Hortikultura, Fak. Pertanian, Institut Pertanian Bogor, Bogor.

Ardiyani, F dan R. Arimarsetiowati. 2012. Pengaruh Penambahan Auxin terhadap Pertunasan dan Perakaran Kopi Arabika Perbanyakan Somatik Embriogenesis. Pelita Perkebunan 28(2): 82-90.

Dewi, N. 2016. Pengaruh Ukuran Belah Bonggol terhadap Pertumbuhan Bibit Pisang Raja (Musa Paradisiaca L.). Laporan Penelitian Dosen. Fakultas Pertanian, Universitas Baturaja, BatuRaja.

Eriansyah, M., Susiyanti dan Y. Putra. 2014. Pengaruh Pemotongan Eksplan dan Pemberian Beberapa Konsentrasi Air Kelapa terhadap Pertumbuhan dan Perkembangan Eksplan Pisang Ketan (Musa Paradisiaca) secara In Vitro. Agrologia 1(3): 54-61.

Ernawati, A., A. Purwito, dan J.M. Pasaribu. 2005. Perbanyakan Tunas Mikro Pisang Raja Bulu (Musa AAB Group) dengan Eksplan
Anakan dan Jantung. Bul. Agron. 2(33): 3138.

Hayati, S.K., Y. Nurchayati, dan N. Setiari. Induksi Kalus dari Hipokotil Alfalfa (Medicago Sativa L.) secara In Vitro dengan Penambahan Benzyl Amino Purine (BAP) dan A-Naphtalene Acetic Acid (NAA). Bioma 1(12): Hal. 6-12.

Hutami, S. 2008. Ulasan Masalah Pencoklatan pada Kultur Jaringan. Jurnal Agrobiogen 2(4):83-88

Isnaini, M. 2016. Pertumbuhan Bibit Pisang Raja Bulu Kuning pada Beberapa Jenis Media dan Konsentrasi Magnesium dengan Sistem Hidroponik Substrat. Thesis. Universitas Sebelas Maret, Surakarta.

Kasutjianingati, R. Poerwanto, N. Khumaida, dan D. Efendi. 2010. Kemampuan Pecah Tunas dan Berbiak Mother Plant Pisang Raja Bulu dan Pisang Tanduk (AAB) dalam Medium Inisiasi In Vitro. Agriplus 1(20): 09-17.

Lestari, E.G. 2011. Peranan Zat Pengatur Tumbuh dalam Perbanyakan Tanaman melalui Kultur Jaringan. Jurnal AgroBiogen 7(1): 63-68.

Maslukha, U. 2008. Ekstrak Pisang sebagai Suplemen Media MS dalam Media Kultur Tunas Pisang Raja Bulu (Musa paradisiaca L. AAB Group) In Vitro. Skripsi. Program Studi Hortikultura Departemen Agronomi dan Hortikultura, Fakultas Pertanian Institut Pertanian Bogor, Bogor.

Nisa C. dan Rodinah. 2005. Kultur Jaringan Beberapa Kultivar Buah Pisang (Musa paradisiaca L.) dengan Pemberian Campuran NAA dan Kinetin. Bioscientiae 2(2): 223-36.

Rahayu, B., Solichatun, dan E. Anggarwulan. Pengaruh Asam 2,4-Diklorofenoksiasetat (2,4-D) terhadap Pembentukan dan Pertumbuhan Kalus serta Kandungan Flavonoid Kultur kalus Acalypha indica L. Biofarmasi 1(1): 1-6.

Rainiyati, D. Martino, Gusniwati, dan Jasminarni. 2007. Perkembangan Pisang Raja Nangka (Musa sp.) secara Kultur Jaringan dari 
Eksplan Anakan dan Meristem Bunga. Jurnal Agronomi 1(11): 35-40.

Rainiyati, Lizawati, dan M. Kristiana. 2009. Peranan IAA dan BAP terhadap Perkembangan Nodul Pisang (Musa AAB) Raja Nangka secara In Vitro Jurnal Agronomi 1(13): 51-57.

Samudin, S. 2009. Pengaruh Kombinasi AuksinSitokinin terhadap Pertumbuhan Buah Naga. Media Litbang Sulteng 2 (1) : 62 - 66.

Siregar, I.Z., N. Khumaida, D. Noviana, M.H. Wibowo, dan Azizah. 2013. Buku Varietas Tanaman Unggul Institut Pertanian Bogor. Institut Pertanian Bogor, Bogor.

Supriyati, Y. 2011. Prospek Teknik Kultur Jaringan untuk Pengadaan Bibit Pisang. Edisi 19-25 Oktober 2011 No.3427 Tahun XLII. Balai Besar Penelitian dan Pengembangan Bioteknologi dan Sumberdaya Genetik Pertanian, Bogor.

Wijayani, Y., Solichatun, dan W. Mudyantini. Pertumbuhan Tunas dan Struktur Anatomi Protocorm Like Body Anggrek Grammatophyllum scriptum (Lindl.) Bl. dengan Pemberian Kinetin dan NAA. Bioteknologi 4 (2): 33-40. 